\title{
Power and Violence in Socio-philosophical Context of Contemporaneity*
}

\author{
Olga Chistyakova \\ Department of History of Philosophy \\ Faculty of Humanities and Social Sciences \\ Peoples' Friendship University of Russia \\ Miklukho-Maklaya str., 6 \\ Moscow, Russia 117198 \\ E-mail: olgachis@yandex.ru
}

\begin{abstract}
The author analyzes the most important phenomena of our time - social violence and power - in terms of identifying traditional and modern theoretical models of their relations. The philosophical concepts of $H$. Arendt, J. Bentham, and M. Foucault are presented, being considered through anthropological and social consequences of the relationship of power and violence. The phenomenon of power is shown, on the one hand, as the opposition to violence, and on the other hand, as the starter of the subordinate relations. Special attention is paid to the analysis of a specific model of power described by M. Foucault.
\end{abstract}

Keywords-social violence; power of man over man; Panopticon; power and nonviolence; religion against violence

\section{INTRODUCTION}

The core problem being considered in the article is the theoretical identification of violence as a social phenomenon representing modern society, as well as an anthropological phenomenon, affecting the existential essence of every individual. Social violence is considered from the point of its correlation to the social phenomena of power in traditional and non-traditional understanding.

What can help to alleviate the burden of a postmodern person, dependent on a rapidly changing society, digital media that have created a "digital human" (a product of the $21^{\text {st }}$ century, unthinkable even at the end of the $20^{\text {th }}$ century), on the loss of control over economic and natural resources, diverse regulations, on the impossibility of wholeness and freedom of cultural identity, on the constant tension and conflicts - i.e. everything constituting social violence?

Any philosophical reflection, appealing to relevant views on the study of the phenomenon of violence, presents a clear statement: violence means the power of man over man.

\section{H. ARENDT'S CONCEPT ON CORRELATION OF POWER AND VIOLENCE}

Since the concept of power inevitably arises when

*The publication has been prepared with the support of the "RUDN University Program 5-100" analyzing violence, it seems appropriate to consider the ideas of the American philosopher Hannah Arendt. Georges Sorel argues in his "Reflection on Violence" that violence always demands representation. A war in this regard is always a representation of violence under the guise of the virtuous goals of achieving the universal well-being. War, just like all military conflicts of today, uses the latest revolutionary achievement of the expression of violence - technology. Therefore, according to $\mathrm{H}$. Arendt, the von Clausewitz concept of violence, as well as the Mao Zedong's thesis that "Political power grows out of the barrel of a gun" are obsolete; there is a need for a different analysis of violence and ways of its expression [1]. H. Arendt is interested in the perspective of the expression of violence in the context of the relations of the concepts of "violence", "non-violence" and "power". Her solution to the issue is still relevant despite its age.

Arendt rests on Bertrand de Jouvenel's work "On Power", who also used a dualistic approach to power and violence. Power as an analytical category is understood as a tool for implementing the government, domination, transmission of rules and commands. Power as a practical and selfidentifying category, arising from within the power itself, tends to explain its appearance and existence by the "instinct of domination". Thus, according to de Jouvenel, we almost exert a "justificatory understanding" of power closely associated with violence: power is an activity, expressing (and being expressed by) the instinct of domination over the Other. De Jouvenel concludes that command and obedience are the essence of power without which the latter cannot exist; no other attributes are required for the exercise of power. H. Arendt notes ironically: "If the essence of power is in the effectiveness of the command, then there is no greater power than that which "grows out of the barrel of a gun". B. de Jouvenel and Mao Zedong would have agreed on such a fundamental issue of political philosophy as the nature of power" [2].

Hannah Arendt notes that the described definition of power stems from the Greek antiquity and prevails in the contemporary political discourse. This approach outlines the power as the rule of a person over another person. Yet, $\mathrm{H}$. 
Arendt argues that there is a need in the modern world to broaden the definition of power: "we should add one of the most recent forms of domination, probably the most monstrous and alarming, namely bureaucracy or rule through an intricate system of bureaucracy [italics by the author of the article - O.C.], in which no one can be responsible for governance, and this form of government, strictly speaking, can be called the rule of Nobody, which is one of the most tyrannical forms, since there's no one who could be questioned about the expediency of what has been done or what is happening" [3]. Even if such a person is within the system, he, as a rule, is unable to address the issue being at the same time confident in the need of the ongoing events (including but not limiting to reforms, changes, the introduction of new rules, effective optimizations, etc.). Franz Kafka once ingeniously showed a bureaucratic form of government based on irrationality rather than on reason and pragmatism. Indeed, the modern bureaucracy is the rule of Nobody, impersonal in the causes and results of its activities.

Arendt, however, describes also the opposite tradition of considering the relationship between power and violence, rather than defining the exercise of power through command and subordination. The philosopher connects the emergence of the said tradition with the Republican form of government of the 18th century where "the code of laws ended the power of man over man". Thus, a republic is the power of people who obey law, and not the other people. Regulatory compliance coincides with the citizens' will and under the condition of representative governance is expressed by the principle of the rule of people over those who govern them.

$\mathrm{H}$. Arendt concludes that violence and power are the opposing concepts; violence doesn't stem from the inevitable implementation of authority. Power is always established on the needs of people and serves the organization of their lives; violence, in turn, emerges with the loss, exhaustion of power. Violence as a special, closed, self-sufficient phenomenon that can "rule" without people and without power. Montesquieu's perception of tyranny is thus curious - he argued that tyranny is the most violent yet the leas powerful form of governance.

What is the difference between power and violence and where is the place for nonviolence? According to H. Arendt, power doesn't need justification, as it is an integral part of political structures, but rather needs legitimation. The use of violence, on the contrary, may be justified but never legitimized in the eyes of people. Despite power and violence being intrinsically different phenomena, they usually appear alongside each other. However, power is a primary predominant factor leading to violence under some internal and external conditions. Power always expresses the essence of any government, which is untrue to violence. Violence is instrumental in its nature, always used out of the need for the absolute and total control, as well as its justification. A legitimate question emerges, how does violence realize itself if it replaces the power structures? $\mathrm{H}$. Arendt claims that violence is being established and enforced based on the "super-organization of power" - even despotism arises this way. Thus, in order for violence to emerge, there needs to be the destruction of social and political institutions once established by power never minding its form. Of importance is the excessive and exaggerated chain of command of political and social institutions that at some point becomes so poorly managed that it ceases to operate. This is exactly the process of losing the legal capacity (or even destruction) of some institutions of the late modernity being witnessed nowadays.

H. Arendt concludes that violence always demolishes power: the most effective orders, creating the most perfect forms of subordination (i.e. violence) come from the "barrel of the gun". Obviously, power never comes from the guns. Violence emerges when power is menaced and comes to the full control when power is permanently lost [4]. Own methods of exercising violence necessarily lead to the dissolvent of power. Proceeding from the inconsistent nature of power and violence, it seems to be that there is no power where violence rules. However, Arendt claims the equation of nonviolence to the opposition of violence to be wrong violence can destroy power but it cannot stem from its opposition which is power. Exactly power is the opposition of violence because the latter appears when power is exhausted [5].

The ways of exercising violence are always dehumanizing and therefore wrong and dangerous. That is why, perhaps, H. Arendt insisted that the key point in comprehending violence is the awareness of the means and tools of its implementation. Violence lies on the material artifacts - let us cite the use of the new tech and information resources in modern warfare. Therefore, a person opposes not only violence but also another person as well as the powerful force of technological, material and psychological achievements of mankind. Of course, everything aforementioned will be used in case of violent actions for destructive purposes only.

\section{THE PANOPTICON AS NON-TRADITIONAL MODEL OF POWER (AS DESIGNED BY J. BENTHAM AND M. FOUCAULT)}

Quite often philosophers and theoretical sociologists define violence and its implementation as a total and constant control over a person, his life, movement, behavior, and even thoughts and intentions. The model of a "perfect" prison, Panopticon, is indicative in this regard, allowing implementation of perpetual supervision of each and every person. Its introduction was supposed to happen in all spheres of life - from correctional facilities and prisons to asylums, factories, schools, etc. The idea of Panopticon as a kind of model of power belongs to one of the most prominent English utilitarians Jeremy Bentham, being rediscovered later in Michel Foucault's "Discipline and Punish: The Birth of the Prison" (1975).

J. Bentham while describing the model based on the principle of utility to society, allowing separating the right from wrong, good from bad, valuable from insignificant. The Panopticon was designed as a ring-shaped building with a tower in its center. The tower is riddled with windows overlooking the inner side of the ring. The building is divided into chambers each extending to the entire width of building with each chamber having two windows - one 
internal, located directly opposite the tower's window, and external, allowing sun- and moonlight illuminating the chambers. Thus, with the help of architecture and optical lightning solutions, chambers are always subjected to the observers and guards, found in the inner tower. According to Bentham and - later on - Foucault, such control may be executed not only over convicts but also over the inhabitants of asylums, workers, and even students. Bentham thought the control on the principles of the Panopticon could secure gratifying results in terms of political utility since the supervision is carried out not only by the guards and observers but also by the inmates themselves.

Foucault develops further these ideas yet concentrating on the internal individual self-control instead of focusing on the external one. The Panopticon uses space and light in such a way that every inmate realizes that he could be watched and controlled at every given moment, this awareness giving him the power of self-control. Foucault concludes that constant light and "the watchful eye" work better than pitch black. Therefore, the control with constant visibility of the observed object is a "journey" to where many theaters with individualized and constantly visible lives are found [6]. In the panoptic model, an inmate cannot come into contact with the others and is therefore always an object of information never coming to be a subject of communication.

Creating a theoretical image of the monstrous machine of total control, powered by continuous self-awareness of external observation and emerging fear, Foucault, nevertheless draws the "moral" effect of the Panopticon. The model awakens the conscience of the inmates from the awareness of constant visibility, which is the automatic exercise of power (the power over them). The main purpose of the Panopticon is, therefore, to keep the inmates in a state of power where they are both the subjects and objects [7]. Those included in the monitoring process, aware of these specific conditions, play two roles simultaneously: he assumes responsibility for the containment of power and, at the same time, channels power at own subordination. An inmate is the one to whom power is directed and who simultaneously exercises it against himself. Foucault is convinced that the power's "unexpected structure", expressed through architecture, light, space and human bodies, depersonalizes power, transforms it into automated functioning self-power. Literally, everyone involved in this mechanism can control it. The French philosopher calls this principle of power "the museum of human nature", where the power of the mind is exercised through itself [8].

Just like H. Arendt, M. Foucault departs from the traditional understanding of power, perceived as a causal relationship of command, subordination, and the ensuing discipline. Foucault's reflection on the exercise of power is linked to the idea of a society that transforms into a completely different incarnation. Time radically changes power, as it changes a society. Nowadays the power functions are distributed so as to cover both the society and an individual with total supervision and control. Control and management of everyone are the distinctive features of modern power, the symbolic (yet perhaps a bit hyperbolized) expression of which is the panoptic model of a prison.
Foucault assumed that wherever there's a task to introduce a full-fledged control, a panoptic scheme may be used for the comprehensive observations.

However, the essence of that "manually guided" prison is seen in the re-education even by force. Exploring Foucault's works, researcher L.Yu. Bronzino notes: "The ideal, yet obvious manifestation of power is a prison, being, nevertheless, explored by Foucault in practice... The essence of modern power is in its interlock with knowledge: power is not only the compulsion to do something but also "the power of discourse", meaning the formation of a method of reflection, using which an individual would certainly, without the feeling of coercion, identify himself in a way the authorities want him to" [9].

Indeed, arguing about the implementation of power in applying penalties towards the lawbreakers, Foucault suggests that there should be a change in the approach and the meaning of punishment that should be milder, educating and character building. The philosopher suggests that punishment should be based on the internal life and feelings of a convict. A thief who has lost respect for a private property must be taught this respect once again. A punishment, based on the internal qualities of an individual, coinciding with training and schooling, is more effective than tortures and other methods of exploitation and execution [10].

However, according to Foucault, a punishment should make sense not only for the one found guilty but for the society as a whole - punishment should be representative, indicative. A person accused of a crime is the subject of punishment but the latter shouldn't be applied to everyone because everyone is potentially guilty of the crimes yet to come. It is necessary to move away from physical punishment toward mitigating the impact of re-education and external control. There is no reason in punishment that is beyond the social control, hidden in the depth of the law enforcement. Foucault insists on a "spectacle-like" nature of the punishments putting forward the idea of admitting public (and even kids) to places where the convicts are serving their terms. The Panopticon as a broad social model of the future of society should be public. The mechanics of disciplinary sanctions is ideally controlled by each member of the society, preventing it from becoming a tyranny. Therefore, such place, according to Foucault, should be regarded as "The Garden of Laws" which should be open for visitors on Sundays. The philosopher calls such punishment a "theater" that may be located in any public space [11], available to an observation of people as a fair warning against possible violations.

This is really a one-man-theater with a convict being the lead actor. That kind of the "Foucault Theater" is aimed at creating an illusion, an illusory space, exaggerating the reality in order to scare the future possible criminals. Is it possible to re-educate the criminals this way? Does it really soften the punishment if a convict is constantly objected to public supervision and control, a priori accusing him? Sure, we can talk about some of Foucault's illusions, his imagination but let us pay attention to the long-established 
(also in the Russian society) phenomenon of "prison tourism". People willingly, even for a fee, come to places of serving of punishments to watch how these punishments are carried out, to even "try extreme". Foucault, for sure, proceeded from other tasks. He wanted to coordinate crime and punishment to make the latter public for educational purposes. With all the contradictions this idea is still quite relevant as often the concealment of a crime leads to protests and destructive actions of the masses. Both the Russian and the Western societies have such experience.

Michel Foucault dreamed apparently of a society free from violence and cruelty in various forms. For him, it was a kind of a social project carrying out its functions through self-awareness, self-education, and self-control of a person. The society at the same time only offers a mechanism for the implementation of a mechanism built on the principles of discipline but discipline as technology or "anatomy of power". Foucault writes about the possibility of establishing the panoptic model of power. What an irony in his words: "Is it any surprise that the prison resembles factories, schools, barracks, hospitals, and they all resemble a prison?" [12].

Least of all we would like to witness to a society organized after the Panopticon yet some of its mechanisms are obviously present. Such artifacts seem to be significant phenomena of our time, its symbols, and signs.

\section{CONCLUSION}

Religion in its institutionalized consistency acts as an independent force capable of countering violence alongside secular public organizations. The spiritual foundations of religion a priori contradict the meaning of violence and therefore contribute to the rationalization of social life basing on peaceful and free existence. Religion is not as far from ration as it is often accused to be.

In philosophical terms, religion has an anthropological essence, reflecting the spiritual potential of each person, and therefore contributing to the education of an integral person. A postmodern individual, somewhere tired of secularism, should build his existence on the basis of rational selfrealization along with something Absolute: ideas of good, peace, tolerance, humanism, moral values. We are convinced that philosophical and anthropological essence of religion with its tendency towards rationalism must now come to the fore of scholar discourses and become an object of professional training in the higher education.

\section{REFERENCES}

[1] Arendt, Hannah. Reflections on Violence // Violence. A Reader (Main Trends of the Modern World). Edited by Catherine Besteman. Maine, USA: Palgrave, 2002.

[2] Ibid. P. 26.

[3] Ibid. P. 26.

[4] Ibid. P. 33.

[5] Ibid. P. 34.

[6] Foucault, Michel. Discipline and Punish: The Birth of the Prison // Violence. A Reader (Main Trends of the Modern World). Edited by Catherine Besteman. Maine, USA: Palgrave, 2002. P. 456.
[7] Ibid. P. 456.

[8] Ibid. P. 457.

[9] Bronzino L. Yu. Modern Discourse: Postmodernism in the Context of Non-Classical Sociological Theories. M: RUDN, 2009. P. 199.

[10] Foucault, Michel. Discipline and Punish: The Birth of the Prison // Violence. A Reader (Main Trends of the Modern World). Edited by Catherine Besteman. Maine, USA: Palgrave, 2002. P. 447.

[11] Ibid. P. 450.

[12] Ibid. P. 471. 